\title{
STUDENT'S EXPECTATIONS OF SERVICE QUALITY IN TERTIARY EDUCATION: A COMPARISON BETWEEN PROSPECTIVE AND CURRENT STUDENTS
}

\author{
JW de Jager and AT du Plooy Tshwane University of Technology
}

The competition for quality students in a highly competitive environment between newly formed tertiary institutions necessitates the employment of managerial techniques to improve the efficiency and quality of their provisions. By examining the factors that influence the buying decisions of prospective and existing students, the most important service quality variables are determined to enable an institution to attract quality prospective students and reduce dropout rates. The overall objective of the article is to determine the most important service quality variables for predegree and degree students when deciding on an educational institution. The most important identified factors that influenced buying decisions among prospective and existing students, in order of importance, were security on campus, computer and library facilities, academic reputation of the institution and reasonable class fees.

Keywords and phrases: service quality, higher education, marketing

\section{INTRODUCTION}

Measuring service quality at higher education institutions worldwide is a common phenomenon (Aldridge \& Rowley, 1998; Athiyaman, 1997; Oldfield \& Baron, 2000). Until recently, it was assumed that the importance of attributes considered when evaluating a tertiary institution are similar for all levels of students. However, various studies have found that there are differences in perceptions of service quality elements and have concluded that these elements have changed over the duration of studies (Oldfield \& Baron, 2000; Moogan, Baron \& Bainbridge, 2001). Hill's (1995) study focuses only on first and final year students, but advocates the need to research prospective students' needs. The aim of this paper is to investigate the importance of key attributes when assessing tertiary institutions and the extent to which these elements are viewed differently between prospective and current students. Challenges in the tertiary education sector and the marketing aspects thereof, with specific reference to the service quality associated with the service package provided to students, are reviewed.

\section{THEORETICAL BACKGROUND}

\section{Global Challenges in the Tertiary Education Sector}

Over the past few years, higher education institutions have experienced dramatic changes, in their structuring, funding and student numbers. The tertiary education sector in South Africa faces many new challenges, including more recently various mergers and the transformation of technikons into universities of technology. This transformation has not only brought about a change of status in these institutions, but also the mergers of intrinsically different institutions. The broadening of access to higher education under the present government policy has seen a growth in the number of applications to tertiary institutions (Bunting \& Cloete, 2004). Milliken and Barnes (2002) report that this has been the case in the last decade in the United Kingdom under the Labour Party. The aim of British and South African educational policy has been based on the perceived link between national levels of educational attainment and economic growth. Whereas the logic of the British government has been that free competition between tertiary institutions will act as a stimulus for improvement and performance, the South African government has taken a more structured approach due to the legacies of an inherited system of education and should also be seen in the context of its broader aim of educational equality (Luescher \& Symes, 2003). 
Tertiary education has experienced a dramatic decline in government subsidies and an increase in student fees in countries such as the United Kingdom and Australia (Palihawadana, 1999; Soutar \& Turner, 2002) that have similar educational systems to South Africa. This is due to various changes in the respective environments. In South Africa, the decline in funding from subsidies is also a direct consequence of the trend of falling pass rates (Naidoo, 2003). It appears as if tertiary institutions face increasing market and financial pressures in all three countries. The result has been a more competitive educational environment.

Given the above background, the effects of competition on institutions of higher education, especially in the South African context, can be seen as having far-reaching implications for these institutions. Traditionally, technikons and universities have competed indirectly, whereas they now compete directly, ostensibly for the same market. This increased level of competition in the education environment has led to institutions of higher education employing managerial techniques to improve the efficiency and quality of their provisions (Palihawadana, 1999) and switch from a passive to a more active market approach (Naudé \& Ivy, 1999).

\section{Marketing in the Tertiary Education Sector}

Etzel Warker and Stanton (2004:208) define a product in a narrow sense as a set of basic attributes assembled in an identifiable form. In addition a product is identified by a commonly understood descriptive name, such as, gold, hairdressing and education. In this narrow definition, features like after service do not play any role. Perreault and M cCarthy (2003) define a product as a total needsatisfying offer that a firm provides. This require a "total" product offering that is a combination of excellent service, a physical good with the right features, useful instructions, a convenient package, a trustworthy warranty and perhaps a familiar name that has satisfied consumers in the past. Thus can a product be a physical good or a service or a blend of both. Etzel Warker and Stanton (2004:208) argue that a broader definition of a product is needed to indicate that customers are not really buying a set of attributes, but rather benefits that satisfy their need. In this sense it can be argued that students do not buy a university or part thereof but the ability to get an acceptable work in the labour market.

Solomon and Stuart (2004) distinguish among three distinct layers of a product - the core, actual, and augmented layers. In developing product strategies, marketers need to consider how these levels should be satisfied. A tertiary institution primarily sells a core service, training. However the service is often directly linked to other services or physical products that support the core service.

The core product/service consists of all the main benefits the product or service will provide for consumers or business customers (Solomon \& Stuart, 2004; Strydom, 2004). In a tertiary institution, the core product can be regarded as the educational training that a student receives. According to Ivy and Naudé (1999) the most basic level is the core benefit that is being sought - students are not buying degrees, they are buying the benefits that the degree can provide in terms of employment, status and life style.

The second level of the product, the actual product, is the physical good or service that supplies the desired benefit (Solomon \& Stuart, 2004). Strydom (2004) identifies five categories of the product attributes. This is the quality level, features (or physical characteristics), styling (or design), a brand name and packaging. At a tertiary institution, this may include the buildings and equipment, supportive facilities like library and computer facilities used in the training process, as well as the persons that are providing the training (Naude \& Ivy, 1999).

The augmented product/service comprises all supporting features that relates to the core product or service. In order to attract customers, a service firm often attempts to offer value added services. This implies additional service offerings that differentiate the firm from the competition. Augmented services may be necessary to provide the core service. In a tertiary institution, this may include intangible attributes (Naude \& Ivy, 1999) such as services provided to schools to inform prospective 
students about the courses offered, financial support like loans and bursaries available for a specific course, extramural activities at the institution, library membership and other on campus activities offered.

Strydom (2004:106) adds a fourth dimension of a product that arises from the tangible and augmented features of the product called the product or service image that is conveyed to the consumers. In order to convey a superior image of a particular tertiary institution, emphasis may be placed on international and national standing in the education environment, the reputation of its courses and the number of research outputs of the institution. Landrum, Turrisi and Harless (1998) agrees that the image of institutions of higher education has a huge influence on the attitudes of their publics toward them and the image that will impact on a student's willingness to apply to that institution for enrolment. Ivy (2001) states that word of mouth, past experience and marketing activities of the institution (e.g. open days at the university, addressing potential students at school, offering bursaries) form the basis of these images and is of the opinion that an institution's actual quality is often less important than its reputation for quality, because it is their perceived excellence which guides the decisions of prospective students and scholars.

Higher Education Institutions should understand their own offerings and how these are perceived in the market place, because it could have important marketing and management implications. Various factors influence the choice of potential scholars to study at a specific tertiary institution, including location (Ford, Joseph \& Joseph, 1999; Roberts \& Allen, 1997), reputation of academic quality (Landrum, Turrisi \& Harless, 1998; Ivy, 2001), course specifics, (Ford, Joseph \& Joseph, 1999) and career opportunities (Ford, Joseph \& Joseph, 1999; Krone, Gilly, Zeithaml \& Lamb, 1981). A recent study by the Human Sciences Research Council (HSRC) in South Africa has found that the most important influence upon choice of institution is its reputation followed by the geographical location. One of the reasons why location is important for students in South Africa is due to the fact that more than a third of all learners do not have a suitable, quiet place in their homes to study (Cosser, 2002) and might use library facilities to study.

According Jobber (2004:806) a scale called SERVQUAL has been developed to assist the measurement of service quality. In SERVQUAL Parasuruman, Zeithaml, and Berry, 1998), five generic dimensions of service quality are suggested namely; responsiveness, reliability, empathy, assurance, and tangibles. However, many subsequent studies of service quality in a variety of services, have failed to recover the five dimensions of service quality (Buttle, 1996). The findings on the factors of Higher Education Service Quality diverge-such as the factor structure identified by Ford, Joseph and Joseph (1999) including academic reputation, career opportunities, programme issues, physical aspects, location, and other. Oldfield and Baron (2000) suggest that there are three underlying factors of higher education service quality namely, requisite elements (encounters which are essential to enable students to fulfill their study obligations), acceptable elements (which are desirable but not essential to students) and functional elements (which are of a practical or utilitarian nature). Cheng and Tam (1997) came to the conclusion based on different conceptions of education quality and the different concerns about achievement of education quality, various people may use diverse indicators to assess education quality and miscellaneous strategies to achieve education quality. It may result in not including all aspects of the input, process and outcome of an education institution. Consequently, this article will focus on the factors emerging from the data.

\section{Measuring Service Quality in the Tertiary Education Sector}

The marketing literature suggests several customer satisfaction measurement approaches. This includes expectation - performance ratings, importance - performance ratings, pure satisfaction ratings and performance only (Lamb, Hair, McDaniel, Boshoff \& Terblanche, 2004:5; Kotler \& Clark, 1987). The most suitable approach is consequently debated. 
The expectations and wants of consumers play an important role in assessing the services of an enterprise. According to Berry and Parasuraman (1991), this implies that service quality is assessed by clients by comparing what they want or expect, and their perception of what they get. The above mentioned indicates that service quality can be assessed by either measuring customer's expectations or the extent of importance that attributes carry and then compare one of the two with their perception of the service.

Hill and McCrory (1997) argued that expectations may be inferred from importance ratings on the grounds that if a consumer believes a service attribute to be important, he/she would expect the quality of that attribute to be good. Carman (1990) points out that for most service providers, the importance of a particular service attribute to consumers seems more relevant than its expected level.

McElwee and Redman (1993) emphasise undergraduate students' lack of knowledge and experience with higher education and therefore have no comparative base or framework of reference from which to make evaluations while, Oldfield and Baron (2000) are of the opinion that it is unlikely that students who had been at an institution for a longer period of time are able to retrospectively rate their expectations in a way that was not influenced by their experiences. It could be argued that the importance/ performance approach may be a more suitable measurement of service quality in higher education and can provide practical guidelines for the development of marketing strategies for institutions of higher education (Ford, Joseph \& Joseph, 1999). For this reason, the decision was made to measure importance rather than expectations. However, it is agreed that measurement of the latter is also important and interrelated in the measurement of service quality.

The issue of when to measure service quality is an important consideration and various studies, including in the higher education sector, have been undertaken to illustrate the influence of timing service quality. Hill (1995) advocates a continuous assessment and management of students' expectations before, at the point of arrival and after their time at a higher education institution. Oldfield and Baron (2000) warn against the assumption that students across all years, require exactly the same types and levels of services and suggest that management should measure and adapt to needs of students that may alter over time. Institutions should be aware and responsive to the factors that influence students over their whole study period and adapt their marketing efforts accordingly (Moogan, Baron \& Bainbridge, 2001). Keeping this in mind the importance of predetermined service quality elements between prospective students and current students will be evaluated and compared with each other. This is done to identify the most important service quality variables and to consequently plan and to make provision for the student's higher education needs.

\section{OBJECTIVE OF THE ARTICLE}

The primary objective of the article is to determine the most important service quality variables for predegree and degree students when deciding on an educational institution.

\section{RESEARCH METHODOLOGY}

\section{Conceptualising the Purpose of the Investigation}

In order to achieve the primary objective of the research, a factor structure was determined of the service quality variables that students regard as important before deciding on an educational institution.

The following secondary objectives were formulated:

- $\quad$ Evaluate the expressed levels of importance of the pre-degree and degree students with regard to these identified variables;

- $\quad$ To determine the existence of significant differences between the pre-degree and the degree students with regard to their expressed levels of importance with the variables. 


\section{Research Hypotheses}

With regards to the objectives, the researchers formulated the following hypotheses:

- Ho: There exists no significant differences with regard to the importance of the service variables between the pre-degree sample and the degree sample.

- $\quad$ Ha: There exists significant differences with regard to the importance of the service variables between the pre -sample and the degree sample.

\section{The Sample Framework}

A sample of 250 pre-degree and 250 degree students at a South African university's management faculty were selected at random. The sample comprised $51 \%$ male and $49 \%$ female students. The attitudes of the two student samples were tested regarding the importance of certain pre-identified service quality issues when making a decision about selecting a specific institution. A list of variables was generated after an extensive literature study was conducted, as well as focus groups consisting of students and lecturers employed by the university. The questionnaires were completed anonymously in pre-determined classes.

\section{The Measuring Instrument and Reliability Measures}

A structured questionnaire was used as a measurement instrument. The measurement instrument included twenty-three variables that are related to service quality at a higher educational institution. A five-point Likert-type scale was used to measure the levels of importance with regards to service quality related issues at the institution of higher education. Respondents were asked to indicate the levels of importance with regard to pre-identified service quality variables, with one being very important and five not important at all.

An item analysis was carried out to test the validity and the reliability of the questionnaire and an overall Cronbach's alpha of a 0,92 was obtained. A two- sample t test was conducted to test the null hypothesis and the alternative hypothesis that there exists no significant difference between the levels of importance between the two groups and there exists significant differences between the groups (pre - degree- and degree students).

\section{Data Analysis and Findings}

\section{Determining the factor structure of the after service evaluation}

A factor structure was developed for the student's expressed levels of importance. This was achieved through identifying those items that correlate highly with several of the items in the questionnaire and which are relatively independent of one another. Only data items with loadings higher than 0,5 were selected. In addition, only factors with an eigenvalue of 1.0 and higher were used in the study. The following two criteria served as guidelines to label the individual factors namely:

- $\quad$ Each identified factor has to explain a relatively large proportion of the variance found in the study variables.

- $\quad$ Every identified factor must be more or less independent of every other factor.

The four identified factors (factor pattern) namely, operational activities, auxiliary services, reputation of the institution and admission requirements, explained $57 \%$ of the total variance of the students service evaluation. Determining the levels of importance of the students will thus provide users of the information with a fairly good framework on which to base intervention strategies. 


\section{Findings of the Study}

The main findings of the study are discussed by first comparing the pre-degree students and the degree student's evaluations with regard to each of the four individual groupings as identified in the previous section.

\section{Table 1: Operational activities}

\begin{tabular}{|l|l|c|c|c|c|c|}
\hline \multicolumn{2}{|c|}{} & Loading & $\begin{array}{c}\text { Mean } \\
\text { Total }\end{array}$ & $\begin{array}{c}\text { Mean } \\
\text { Pre- } \\
\text { Degree }\end{array}$ & $\begin{array}{c}\text { Mean } \\
\text { Degree }\end{array}$ & $\begin{array}{c}\text { Mean } \\
\text { Difference }\end{array}$ \\
\hline V99 & $\begin{array}{l}\text { Distance to institution is far } \\
\text { away from home }\end{array}$ & 0.55 & $2.51(4)$ & 2.56 & 2.48 & 0.08 \\
\hline V100 & $\begin{array}{l}\text { Distance to institution is close } \\
\text { to my home }\end{array}$ & 0.71 & $2.78(7)$ & 2.78 & 2.78 & 0 \\
\hline V101 & Availability of public transport & 0.71 & $1.92(2)$ & 1.80 & 1.98 & -0.18 \\
\hline V102 & Parking & 0.73 & $2.72(6)$ & 2.91 & 2.63 & $0.28^{\star *}$ \\
\hline V103 & Security on Campus & 0.58 & $1.42(1)$ & 1.35 & 1.45 & -0.10 \\
\hline V104 & Hostel accommodation & 0.64 & $2.55(5)$ & 2.74 & 2.47 & 0.27 \\
\hline V105 & $\begin{array}{l}\text { Private accommodation near } \\
\text { institution }\end{array}$ & 0.56 & $2.39(3)$ & 2.50 & 2.34 & 0.16 \\
\hline
\end{tabular}

** = Significant differences on a $90 \%$ level of significance

Overall, the most important variable measured in this category (table1) is security on campus. Predegree students regarded this issue slightly more important compared to the degree students. The availability of public transport was overall rated as the second most important issue, while pre-degree students rated it slightly more important than degree students. Both issues were rated between very important and important.

Overall, the two least important issues in this category appeared to be that distance to institution is close to their home. It appears as if both groups agree on the issue. It appears as if distance can be seen as more of an advantage than a strain. This may imply that the students prefer to become independent and to stand on their own feet, or due to lack of a suitable study environment at their own homes.

\section{Table 2: Auxiliary services}

\begin{tabular}{|l|l|c|c|c|c|c|}
\hline \multicolumn{2}{|l|}{} & Loading & $\begin{array}{c}\text { Mean } \\
\text { Total }\end{array}$ & $\begin{array}{c}\text { Mean } \\
\text { Pre- } \\
\text { Degree }\end{array}$ & $\begin{array}{c}\text { Mean } \\
\text { Degree }\end{array}$ & $\begin{array}{c}\text { Mean } \\
\text { Difference }\end{array}$ \\
\hline V112 & Financial aid available & 0.59 & $1.77(3)$ & 1.86 & 1.73 & 0.13 \\
\hline V113 & Computer facilities & 0.68 & $1.46(1)$ & 1.46 & 1.45 & 0.01 \\
\hline V114 & Library facilities & 0.56 & $1.46(1)$ & 1.59 & 1.41 & 0.18 \\
\hline V115 & Recreation Facilities & 0.74 & $1.93(4)$ & 1.97 & 1.91 & 0.06 \\
\hline V116 & Extramural activities & 0.80 & $2.25(5)$ & 2.36 & 2.20 & 0.16 \\
\hline V117 & Ethnical diversity & 0.62 & $2.35(6)$ & 2.50 & 2.28 & $0.22^{\star \star}$ \\
\hline
\end{tabular}

** = Significant differences on a $90 \%$ level of significance

The two variables that tested equally most important in this category (table2) were computer and library facilities. Degree students rated library facilities slightly more important than pre- degree students, while computer facilities were rated almost equally important. Another issue of great overall concern is financial aid available for tertiary education. A factor that may contribute to this outcome is the large unemployment rate in South Africa. Currently, the government is making large amounts of 
money available for tertiary education in the country. Degree students regarded this issue slightly more important compared to the pre-degree students. This is probably because they already experience the full financial burden. Ethnic diversity was overall regarded as least important, followed by extramural activities.

Table 3: Reputation of institution

\begin{tabular}{|l|l|c|c|c|c|c|}
\hline \multicolumn{2}{|l|}{} & Loading & $\begin{array}{c}\text { Mean } \\
\text { Total }\end{array}$ & $\begin{array}{c}\text { Mean } \\
\text { Pre- } \\
\text { degree }\end{array}$ & $\begin{array}{c}\text { Mean } \\
\text { Degree }\end{array}$ & $\begin{array}{c}\text { Mean } \\
\text { Difference }\end{array}$ \\
\hline V106 & $\begin{array}{l}\text { Academic reputation of } \\
\text { institution }\end{array}$ & 0.62 & $1.48(1)$ & 1.47 & 1.49 & -0.02 \\
\hline V108 & Academic reputation of faculty & 0.77 & $1.52(2)$ & 1.54 & 1.52 & 0.02 \\
\hline V109 & $\begin{array}{l}\text { Reputation of lecturers at } \\
\text { institution }\end{array}$ & 0.62 & $1.57(4)$ & 1.64 & 1.55 & 0.09 \\
\hline V110 & $\begin{array}{l}\text { Availability of information } \\
\text { about faculty }\end{array}$ & 0.60 & $1.53(3)$ & 1.50 & 1.53 & -0.03 \\
\hline
\end{tabular}

Overall, the most important issue under this category (table 3 ) is the academic reputation of the institution. Both study groups agreed on the issue. Both the academic reputation of the faculty and the availability of information about the faculty were overall rated as the second most important issue. The same trends were noticed for both groups. The variable rated as the least overall important issue is the reputation of the lecturers at the institution.

Table 4: Admission requirements

\begin{tabular}{|l|l|c|c|c|c|c|}
\hline & Loading & $\begin{array}{c}\text { Mean } \\
\text { Total }\end{array}$ & $\begin{array}{c}\text { Mean } \\
\text { Pre- } \\
\text { degree }\end{array}$ & $\begin{array}{c}\text { Mean } \\
\text { Degree }\end{array}$ & $\begin{array}{c}\text { Mean } \\
\text { Difference }\end{array}$ \\
\hline V98 & Size of institution & 0.75 & $3.33(5)$ & 3.35 & 3.32 & $0.03^{\star \star}$ \\
\hline V118 & Small classes & 0.52 & $2.48(4)$ & 2.76 & 2.36 & $0.40^{\star \star}$ \\
\hline V119 & Reasonable class fees & 0.65 & $1.54(1)$ & 1.60 & 1.51 & 0.09 \\
\hline V120 & $\begin{array}{l}\text { Reasonable admission } \\
\text { requirements }\end{array}$ & 0.71 & $1.64(2)$ & 1.75 & 1.60 & $0.15^{\star \star}$ \\
\hline V121 & Strict admission requirements & 0.56 & $2.22(3)$ & 2.57 & 2.06 & $0.51^{\star \star}$ \\
\hline
\end{tabular}

** $=$ Significant differences on a $90 \%$ level of significance

Overall, reasonable class fees were rated as the most important issue in this category (table 4). According to Cloete, Pillay, Badat and Moya (2005), one of the main reasons for the high drop out figure in South Africa is because of financial constraints. A similar trend was noticed between predegree students and degree students while the degree students rated it slightly more important compared to pre-degree students. Reasonable admission requirements were rated as the second most important issue in this category while degree students rated it as more important than predegree students.

The least important issues as rated by the overall sample were the size of the institution, followed by the availability of relatively small classes.

\section{CONCLUSION AND RECOMMENDATIONS}

From the empirical study, four factors were identified namely, operational activities, auxiliary services, reputation of the institution and admission requirements. The four factors explained $57 \%$ of the total variance of the student's service evaluation. The factors will be explained while recommendations to the management will consequently be given. 


\section{Operational Activities}

Under operational activities, the security on campus and the availability of public transport were rated by the two distinctive groups as the most important two variables in this category. In addition security on campus was rated overall as most important variable from the list of service quality variables.

As a result of the high crime rate that is experienced by most citizens in the Republic of South Africa, the security measures on campus should be maintained at a high level and the visibility of security officials should increases. Technologically advanced security methods should be implemented to secure classrooms and to prevent cases of theft from classrooms such as overhead projectors and data projectors. This could include an electronic card system to monitor entrance to classrooms and to prevent unauthorised entrance.

The provision of acceptable public transport (where possible) should be maintained, as there is a great demand by the majority of students that are dependant on these services. While the institutions of higher education are to some extent in control over their own transport system transporting students to and fro hostels, care should be taken to ensure that metro busses provide the necessary back up services for students.

\section{Auxiliary Services}

Computer and library facilities were both regarded equally most important factor in this category. This implies that students are aware of the importance of technologically advanced equipment in a higher educational institution. The availability of financial aid has been rated second most important issue.

Computer facilities were rated as the second overall most important issue from the list of variables. Provision should be made to budget on a regularly basis for the upgrading of computer hardware and software in order to establish a competitive advantage over other educational institutions. Training that involves the use of highly technologically advanced equipment where applicable, should be encouraged in a competitive higher education environment.

Attracting and managing financial aid (e.g. the provision of study loans by the government) should be high on the agenda. The need to this issue is also noticeable in the admission requirement category and will be dealt with there.

\section{Reputation of the Institution}

Factor three, the reputation of the institution, tested the academic reputation of the institution and the academic reputation of the faculty as the two most important issues in this category.

As the overall third most important variable associated with the selection of an institute for higher education, the reputation of the institution should be built and maintained. Maintaining high quality of training that is compared internationally should be envisaged. International partnerships in training should be searched and the existence thereof should be emphasized in internal and external communications with employees, alumni and the community. Active involvement in service to the community should be encouraged as standard practice. The importance and power of word of mouth communication should not be under estimated. Academic institutions active involvement in research of acceptable standard will ensure a good national academic standing, not only compared to other national tertiary institutions, but also compared to international institution's standing.

\section{Admission Requirements}

Factor four tested admission requirements. Reasonable class fees and reasonable admission requirements were rated the most important issues. 
Factors like a relatively high unemployment rate as well as the fact that many of the students are from the previously disadvanced population group, contributes to the need of acceptable class fees. Provision on campus should be made to render the necessary service to accommodate students who may apply for government assistance. The provision of bursaries and sponsorships by the private sector should also be encouraged and managed through a centralised office. While reasonable admission requirements sounds "reasonable" it should be stated that the most promising students, that are able to complete their studies in the minimum time period, should get priority. The reason is that that the fall out rate of students in higher education in South Africa is very high, which consequently influence the subsidy from government negatively (Naidoo, 2003). As institutions of higher education is also restricted in terms of growth, care should be taken to ensure that the most promising students be recruited in order to gain admission.

\section{REFERENCES}

Aldridge S \& Rowley J. 1998. Measuring Customer Satisfaction in Higher Education. Quality Assurance in Education, 6(4): 197-204.

Athiyaman A. 1997. Linking Student Satisfaction and Service Quality Perceptions: The Case of University Education. European Journal of Marketing, 31(7): 52-540.

Berry LL\& Parasuraman A. 1991. Marketing services. Competing through quality. New York: The free press.

Buttle F. 1996. SERVQUAL: Review, Critique, Research Agenda. European Journal of Marketing, 30(1).

Bunting I \& Cloete N. 2004. Approaches to Measuring Performance in Higher Education: A South Africa Case Study. Draft Discussion Paper. Council on Higher Education Policy/Change Dialogue. Cape Town.

Cheng Y \& Tam WM. 1997. Multi Models of Quality in Education. Quality assurance in Education, 5(1): $22-31$.

Cloete N, Pillay P, Badat S \& Moya T. 2005. National Policy and a Regional Response in South African Higher Education. Cape Town: Oxford.

Cosser M. 2002. Majority Seeking Higher Education HSRC. Business Day 1st Edition.

Etzel MJ, Walker BJ \& Stanton WJ. 2004. Marketing. 13th Edition. New York: McCraw-Hill.

Ford JB, Joseph M \& Joseph B. 1999. Importance-Performance Analysis as a Strategic Tool for Service Marketers: The Case of Service Quality Perceptions of Business Students in New Zealand and the USA. The Journal of Services Marketing, 13(12): 171-186.

Hill FM. 1995. Managing Service Quality in Higher Education: The Role of the Student as Primary Consumer. Quality Assurance in Education, 3(3): 10-21.

Hill FM \& McCrory ML. 1997. An Attempt to Measure Service Quality at a Belfast Maternity Hospital: Some Methodological Issues and Some Results. Total quality management, 8( 5): 229 - 243.

Ivy J. 2001. Higher Education Institution Image: a Correspondence Analysis Approach. The International Journal of Educational Management, 15(6): 276-282.

Jobber DJ. 2004. Principles and Practice of Marketing. 4th edition. London: McCraw-Hill. 
Kotler P \& Clarke RN. 1987. Marketing for Health Care Organisations. Englewood Cliffs. Prentice Hall.

Luescher TM \& Symes A. 2003. Higher Education 1997-2003: The Transformation of Higher Education in South Africa: How Much have We Achieved?" Research Report: Perceptions of Policy Developments 1997-2003: and Outlook For The Next Five Years. Council on Higher Education's Fifth Consultative Conference. Benoni.

McElwee G \& Redman T. 1993. Upward Appraisal in Practice. Education and Training, Vol. 35, No. 2 (1993): 27-31.

Milliken M \& Barnes LP. 2002. Teaching and Technology in Higher Education: Student Perceptions and Personal Reflections. Computers and education, 39(3): 223-235.

Moogan YJ, Baron S \& Bainbridge S. 2001. Timings and Trade-Offs in the Marketing of Higher Education Courses: A Conjoint Approach. Marketing Intelligence \& Planning, 19(3): 179-187.

Naidoo S. 2003. Asmal Calls for Controlled Student Intake. Business Day. 1st Edition.

Naudé P \& Ivy N. 1999. The Marketing Strategies of Universities in the United Kingdom. The International Journal of Educational Management, 13(3): 126-136.

Oldfield B \& Baron S. 2000. Student Perceptions of Service Quality in a UK University Business and Management Faculty. Quality Assurance in Education, 8(2): 85-95.

Palihawadana GH. 1999. Modeling Module Evolution in Marketing Education. Quality assurance in Education, 7(1): 41- 46.

Parasuruman A, ZeithamI VA \& Berry LL. 1998. SERVQUAL: A Multiple Item Scale for Measuring Consumer Perceptions of Service Quality. Journal of Retailing, 64: 12-37.

Perreault WD \& McCarthy EJ. 2003. Essentials of Marketing. A global - managerial approach. Boston: McCraw Hill.

Soutar GN \& Turner JP. 2002. Student Preferences for University: a Conjoint Analysis. The International Journal of Educational Management, 16(1): 40-45.

Solomon MR \& Stuart EW. 2003. Marketing: Real People, Real Choices. New Jersey. Pearson Education, Inc.

Strydom J. 2004. Introduction to Marketing. Cape Town: Juta and Co Ltd. 